\title{
Perancangan dan Pengembangan Mainan Anak dari Limbah Triplek Berbasis Smartphone
}

\author{
${ }^{1}$ Tri Prihatiningsih, ${ }^{2}$ Santika, ${ }^{3}$ Trismawati \\ Teknik Industri, Universitas Panca Marga \\ Probolinggo, 67271, Indonesia
}

Email: ${ }^{1}$ tri.prihatiningsih@upm.ac.id, ${ }^{2}$ santika120696@gmail.com, 3trismawati@upm.ac.id

$\overline{\text { Tersedia Online di }}$
http://www.jurnal.unublitar.ac.id/
index.php/briliant

Sejarah Artikel

Diterima pada Agustus 2020

Disetuji pada Mei 2021

Dipublikasikan pada Mei 2021

Hal. 445-453

Kata Kunci:

Limbah; mikrokontroler; wifi; QFD; smartphone

\section{DOI:}

http://dx.doi.org/10.28926/briliant .v3i4.538

\begin{abstract}
Abstrak: Mainan anak telah mengikuti perkembangan teknologi yang dapat menciptakan peluang bisnis. Penelitian ini menghasilkan produk mainan anak berbasis smartphone yang berbahan dasar limbah triplek. Untuk mengoperasikan mainan tersebut, diperlukan mikrokontroler ESP8266 dan smartphone android sebagai alat pengontrol mainan anak. Metode Quality Function Deployment (QFD) digunakan untuk mengetahui keinginan dan kepuasan konsumen. Pengembangan produk mainan anak ini lebih terjangkau harganya dibandingkan mainan anak yang menggunakan remote kontrol yang telah terjual di pasaran.
\end{abstract}

\section{PENDAHULUAN}

Saat ini, mainan anak telah mengikuti perkembangan teknologi (Alia, 2018; Astini et al., 2019; Nisa, 2012), sehingga dapat menciptakan peluang bisnis. Adapun mainan yang banyak dijual di pasaran terbuat dari bahan dasar plastik dan harga yang lebih mahal. Dalam penelitian ini, kami mengusulkan inovasi baru pada mainan anak berbasis smartphone yang terbuat dari limbah triplek. Selain itu, mainan yang diusulkan tidak menggunakan remote kontrol pada umumnya melainkan menggunakan smartphone android. Dalam penggunaan dan pembeliannya, masyarakat mempunyai keluhan tentang kekurangan pada mainan mobil remot kontrol yang sudah ada dan mengharapkan adanya produk baru yang mempunyai kelebihan dari mainan anak sebelumnya, berdasarkan hasil survey awal yang dilakukan peneliti, berikut keluhan konsumen tentang mobil remote kontrol yang sudah ada 1) mudah pecah jika mobil tidak sengaja dijatuhkan dikarenakan terbuat dari plastik, 2) penggunaan remot kontrol yang cenderung cepat rusak, 3) harga yang tidak terjangkau untuk kalangan menengah ke bawah

Dengan adanya adanya keluhan konsumen tersebut, maka peneliti mengusulkan suatu pengembangan produk mainan anak dari limbah triplek berbasis smartphone dengan memanfaatkan wifi, sehingga dapat mengurangi limbah dan 
memiliki harga yang lebih terjangkau. Pada permasalahan penelitian ini, peneliti akan menggunakan metode Quality Function Deployment (QFD) (Suhendar and Suroto, 2014; Wagiono and Hamrah, 2007). Metode tersebut merupakan metode yang sesuai untuk melakukan pengembangan suatu produk. Metode QFD merupakan metode yang mampu mengidentifikasi keinginan konsumen dan kebutuhan konsumen.

\section{METODE}

Penelitian ini dilakukan dalam empat tahap, yaitu tahap pengumpulan data, tahap perancangan, tahap analisis ekonomi, dan tahap perhitungan tingkat kepuasan konsumen.

\section{Tahap Pengumpulan Data}

Pada tahapan ini, pengumpulan data dilakukan secara langsung pada lokasi penelitian. Adapun teknik yang dilakukan yaitu wawancara dan penyebaran kuisioner.

\section{Tahap Perancangan}

Di tahap perancangan, beberapa sub aktivitas dilakukan, dimulai dari survei awal, desain dan perancangan produk, analisis ekonomis dan teknis, serta survei akhir. Survey awal dilakukan dengan analisis Quality Function Deployment (QFD) dengan beberapa atribut, yaitu (1) Desain sederhana, (2) Harga, (3) Bahan, dan (4) Mudah dalam penggunaan. Selanjutnya, survei awal diolah untuk menghasilkan House of Quality (HOQ) (Dewi et al., 2011; Sutawidjaya and Asmarani, 2018) guna mengetahui ranking tiap atribut. Adapun HOQ ditunjukkan oleh Gambar 1.

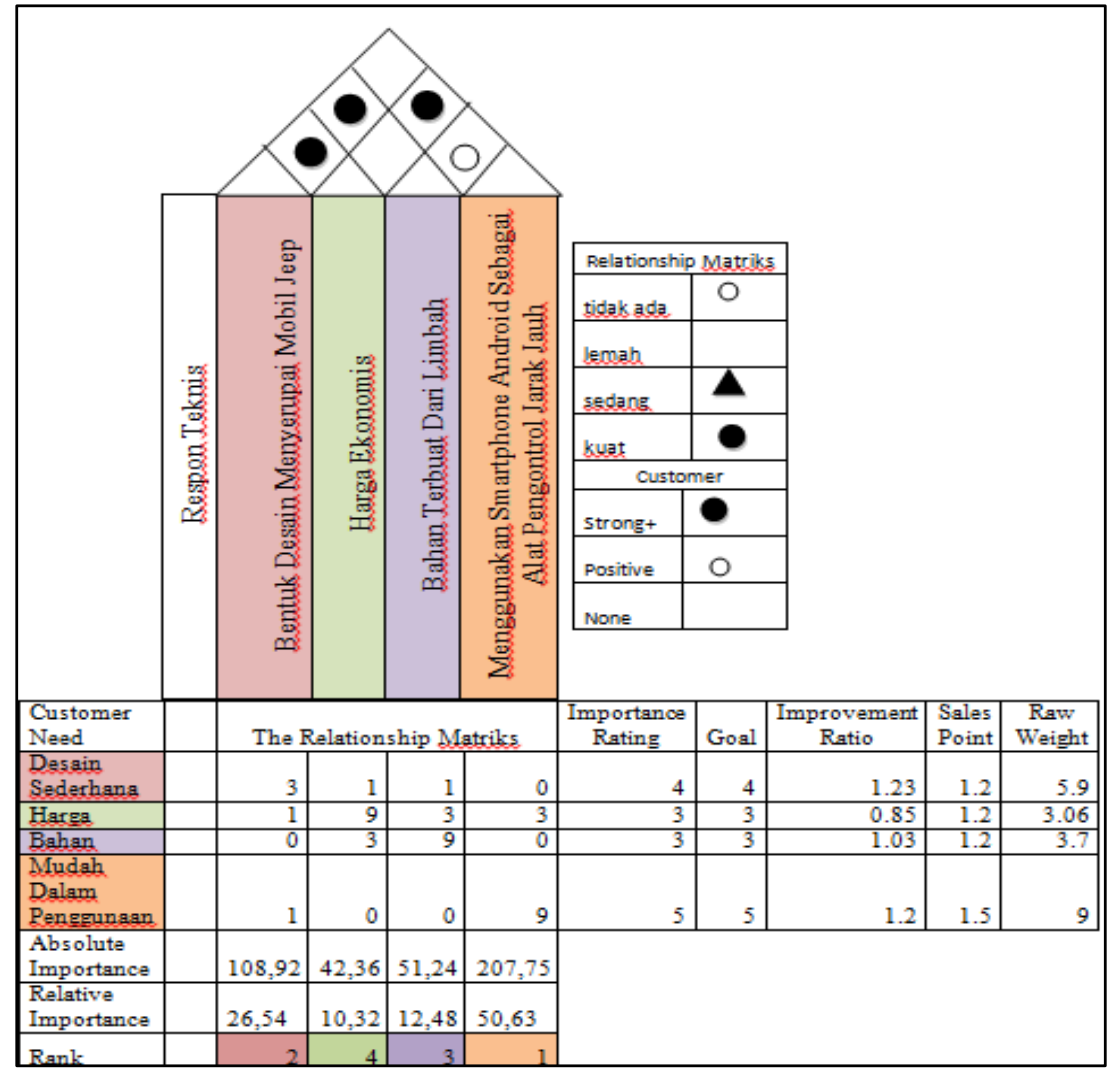

Gambar 1. House of Quality (HOQ) survei awal

446 BRILIANT: Jurnal Riset dan Konseptual Volume 6 Nomor 2, Mei 2021 
Berdasarkan Gambar 1, dijelaskan bahwa ranking pertama pada HOQ adalah atribut (4) mudah dalam penggunaan, yakni sebesar $50.63 \%$, Berdasarkan hasil analisis matrik HOQ, didapatkan bahwa hasil perhitungan bobot dan perankingan pada Tabel 1 . Selanjutnya, tahap perancangan mainan dimulai dari pengumpulan bahan berupa limbah triplek. Setelah itu, triplek dipotong dan dirangkai menjadi produk mainan seperti pada Gambar 2. Setelah melakukan perancangan mainan, selanjutnya adalah melakukan perancangan elemen mainan seperti pada Gambar 3, dimulai dari a) mengupload program ke board node mcu, b) memasang node mcu ke driver motor, c) menyambung kabel positif di ic 7809, d) menyambung kabel ke ground driver motor, e) menyambung kabel ke motor, f) penyambungan kabel ke penggerak motor, dan g) koneksi ke relay 4 channel.

Tabel 1. Hasil ranking dari HOQ

\begin{tabular}{|c|c|c|c|c|}
\hline No & Atribut & Respon Teknis & Ranking & Hasil Bobot \\
\hline 1 & Mudah dalam penggunaan & $\begin{array}{c}\text { Menggunakan smartphone android } \\
\text { sebagai alat control jarak jauh }\end{array}$ & 1 & $50.63 \%$ \\
\hline 2 & Desain Sederhana & Bentuk desain menyerupai mobil jeep & 2 & $26.54 \%$ \\
\hline 3 & Bahan & Bahan terbuat dari limbah & 3 & $12.48 \%$ \\
\hline 4 & Harga & Harga ekonomis & 4 & $10.32 \%$ \\
\hline
\end{tabular}

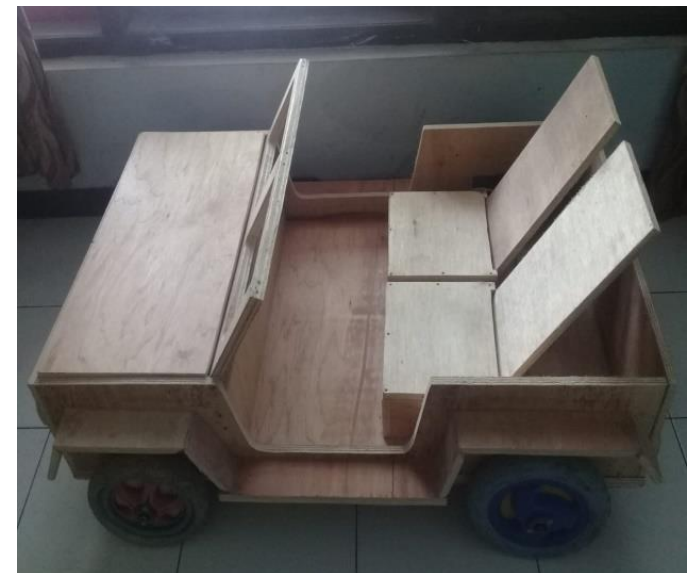

Gambar 2. Desain produk mainan anak dengan proses pengerjaan $80 \%$

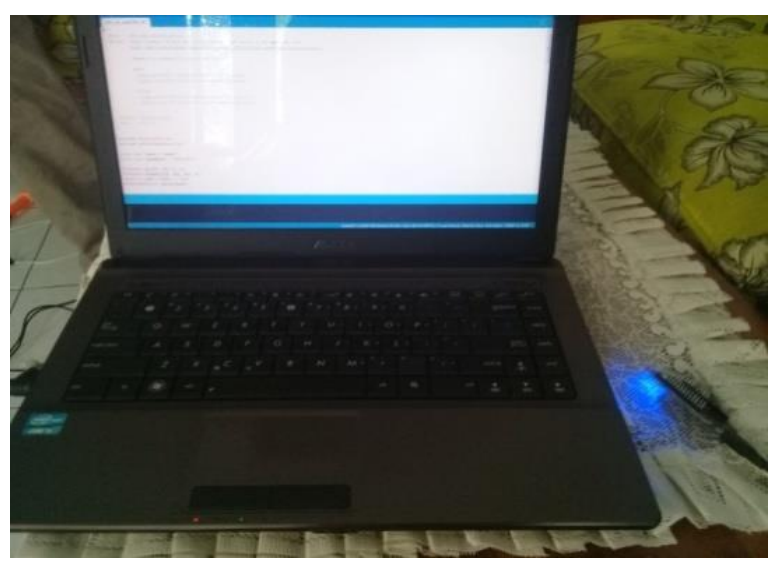

(a)

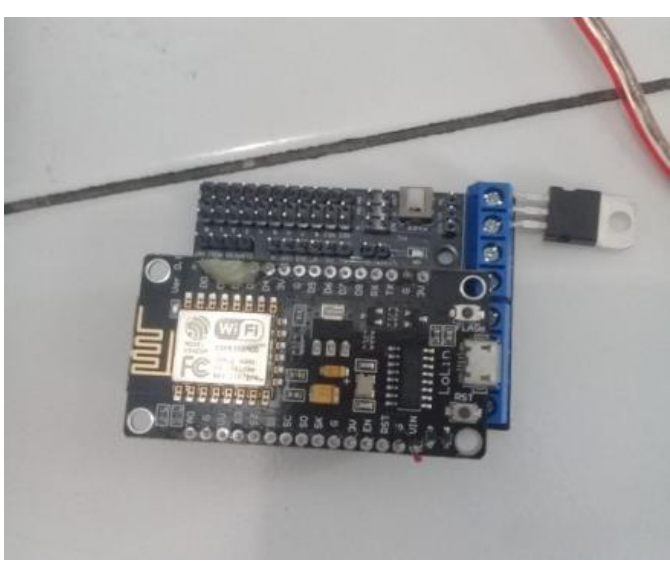

(b)

BRILIANT: Jurnal Riset dan Konseptual

Volume 6 Nomor 2, Mei 2021 


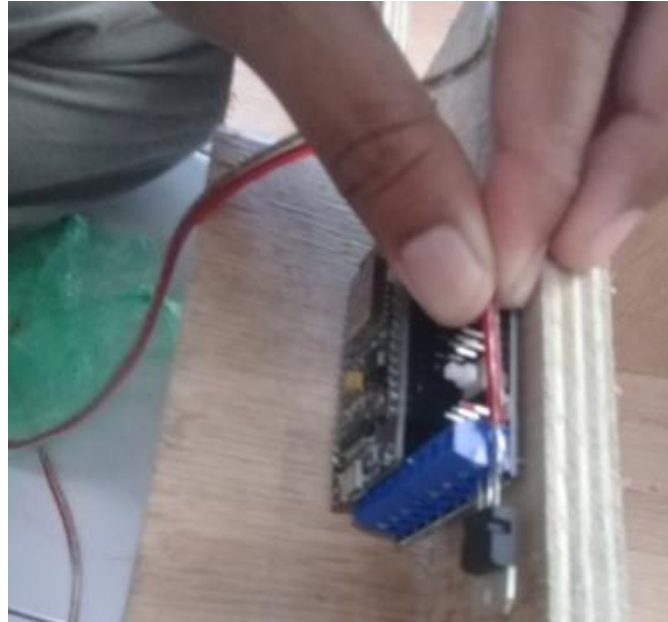

(c)

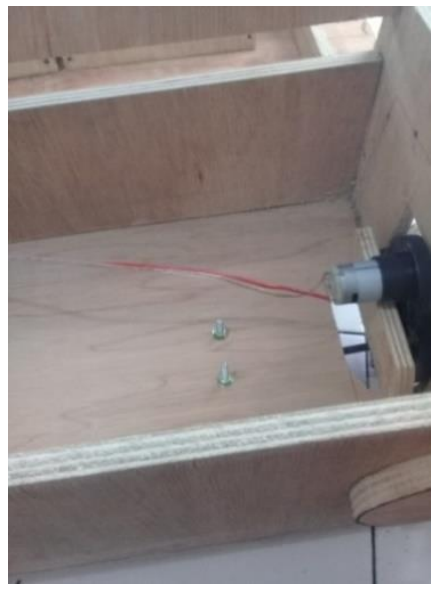

(e)

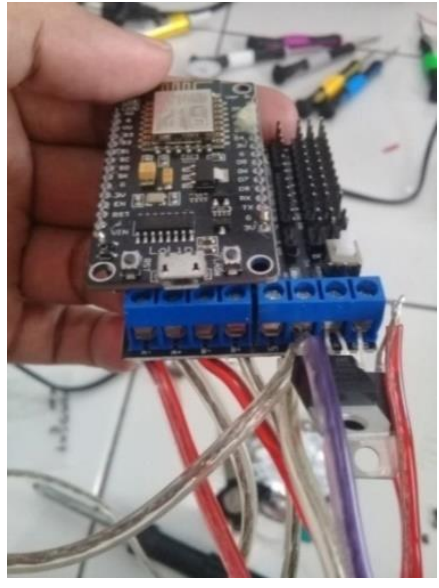

(f)

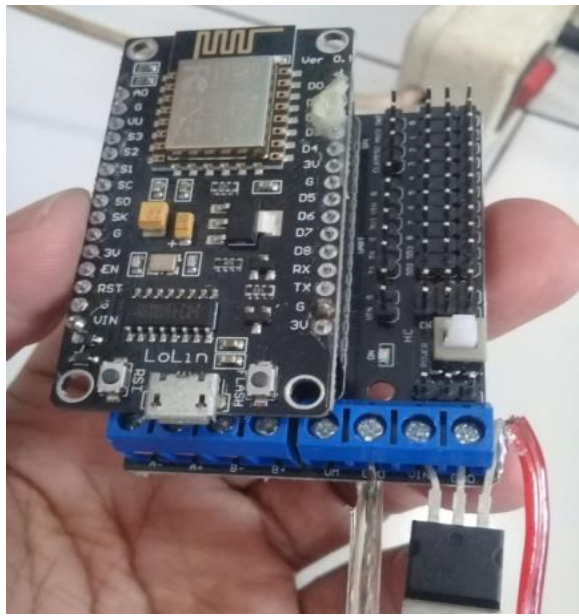

(d)

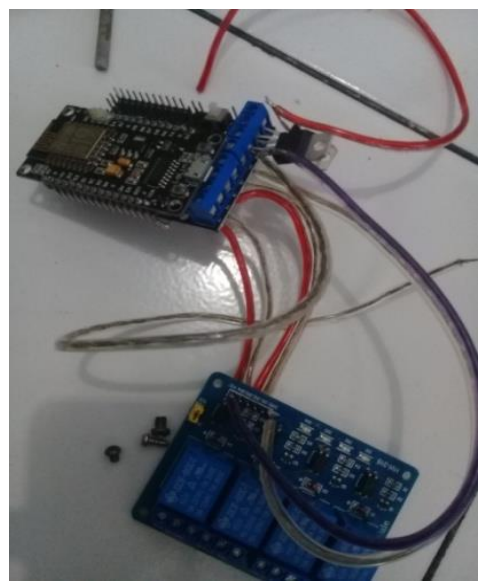

$(\mathrm{g})$

Gambar 3. Proses perancangan elemen mainan.

\section{Tahap Analisis Ekonomi}

Pada tahap ini, peneliti melakukan analisis sumber dana yang dibutuhkan untuk produksi mainan anak, sehingga kami dapat menentukan harga jual mainan yang telah diproduksi. Selanjutnya kami melakukan analisis teknis dan membandingkan kekuatan, bahan, dan harga antara mainan anak yang ada di pasaran dengan mainan anak yang kami produksi.

\section{Tahap Perhitungan Tingkat Kepuasan Konsumen menggunakan metode Quality Functon Deployment (QFD)}

Pengumpulan Hasil survey akhir terhadap kepuasan konsumen peneliti melakukan penyebaran kuesioner kepada 20 orang dengan sample yang sama yaitu customer yang terdaftar di survey awal. Tujuan kegiatan survey akhir ini yaitu untuk mengetahui apakah hasil produk pengembangan mainan anak yang sudah dirancang sesuai dengan apa yang diharapkan oleh customer dan bisa diterima oleh customer atau tidak. Data yang diperoleh dari wawancara kemudian diproses menjadi Voice of Customer (VOC). 


\section{HASIL DAN PEMBAHASAN}

Sumber dana yang dibutuhkan untuk produksi mainan anak yaitu sebesar Rp626.000,00 dengan detail di Tabel 2. Penetapan harga produk dilakukan dengan perhitungan tertentu secara baku dan konsisten, serta berdasarkan pengeluaran dalam membeli bahan dan proses pengerjaan produksi. Adapun harga jual produk mainan ini adalah Rp688.600 per item. Harga yang dipatok ini jauh lebih murah daripada produk mainan yang terjual di pasaran. Tabel 3 menunjukkan perbandingan antara mainan usulan dengan mainan yang telah ada di pasar.

Tabel 2. Analisis modal untuk produksi mainan anak

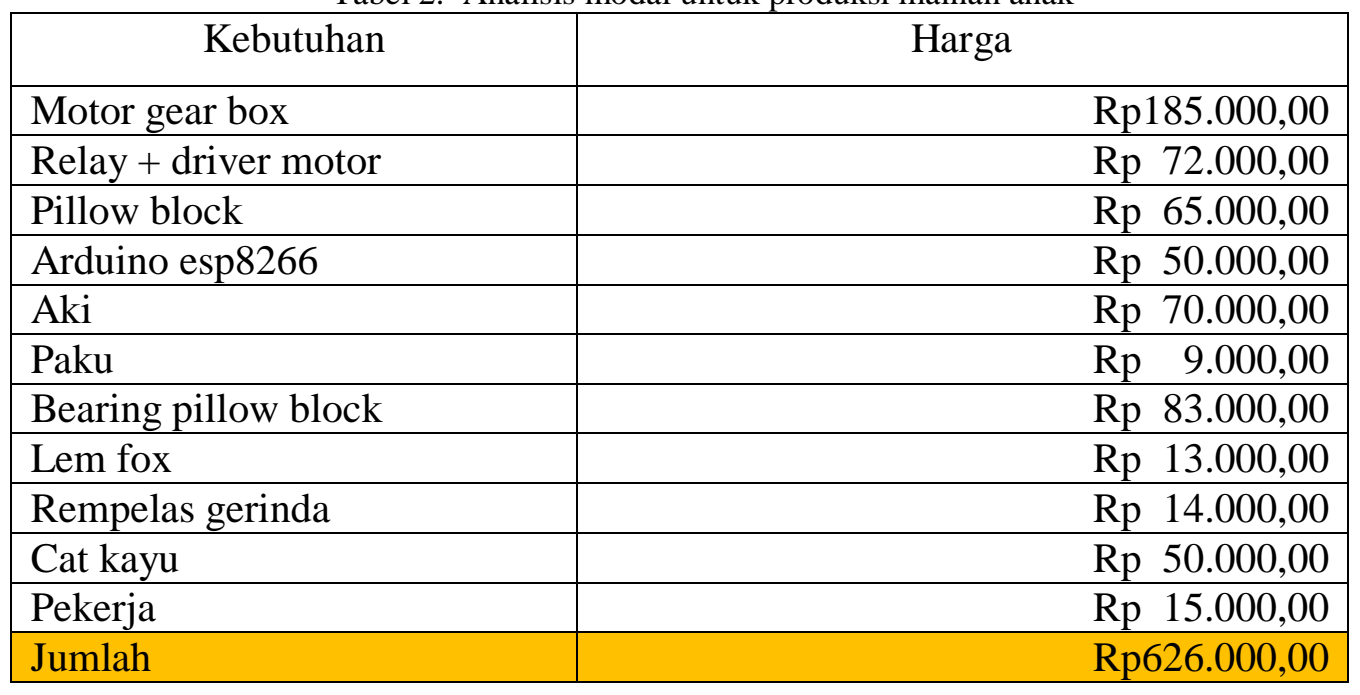

Tabel 3. Perbandingan mainan anak

\begin{tabular}{|l|l|l|l|}
\hline No & Atribut & Produk Lama & Produk Hasil Penelitian \\
\hline 1 & Kekuatan & Mudah patah & Kuat \\
\hline 2 & Bahan & Plastik (mudah pecah) & Triplek (tahan banting) \\
\hline 3 & Inovasi baru & $\begin{array}{l}\text { Menggunakan remot } \\
\text { control }\end{array}$ & $\begin{array}{l}\text { Menggunakan smartphone } \\
\text { android }\end{array}$ \\
\hline 4 & Harga & Mahal (Rp1.500.000,00) & $\begin{array}{l}\text { Lebih terjangkau } \\
\text { (Rp688.600,00) }\end{array}$ \\
\hline
\end{tabular}

Selanjutnya, survey akhir dilakukan untuk menganalisis kepuasan konsumen dengan menyebarkan kuisioner kepada 20 customer yang terdaftar di survey awal. Survey akhir bertujuan untuk mengetahui apakah hasil produk mainan usulan sesuai dengan yang diharapkan customer. Data hasil kuisioner dari survey akhir diperoleh dengan wawancara langsung pada customer kemudian diolah dan dirangkum untuk dijadikan dasar pembuatan Voice of Customer (VOC). Atribut yang digunakan sama dengan survey awal, di mana kuesioner menggunakan skala linket 1-5. Adapun data dari hasil kuesioner yang dilakukan terhadap hasil produk mainan anak bisa dilihat pada Tabel 4.

Selanjutnya, pengukuran tingkat kepuasan konsumen pada hasil produk adalah untuk mengukur bagaimana kepuasaan konsumen tentang hasil produk yang telah dibuat oleh peneliti. Pengukuran kepuasan konsumen sangat penting untuk 
hasil produk yang sudah dirancang, Dari hasil pengukuran tingkat kepuasan konsumen, peneliti dapat mengetahui bagian-bagian mana yang dapat dikembangkan kembali untuk diperbaiki. Adapun hasil perhitungan tingkat kepuasan konsumen terdapat pada

Tabel 5.

Tabel 4. Jumlah responden terhadap atribut hasil produk mainan anak

\begin{tabular}{|c|l|c|c|c|c|c|}
\hline \multirow{2}{*}{ No } & \multirow{2}{*}{\begin{tabular}{c} 
Atribut \\
\cline { 3 - 7 }
\end{tabular}} & $\begin{array}{c}\text { tidak } \\
\text { puas }\end{array}$ & kurang puas & puas & cukup puas & sangat puas \\
\cline { 3 - 7 } & & 1 & 2 & 3 & 4 & 5 \\
\hline 1 & Desain sederhana & 3 & 2 & 5 & 10 & 3 \\
\hline 2 & Harga & 5 & 4 & 4 & 7 & \\
\hline 3 & Bahan & 1 & 3 & 4 & 7 & 5 \\
\hline 4 & Mudah dalam penggunaan & & & & \\
\hline
\end{tabular}

Tabel 5. Tingkat kepuasan konsumen

\begin{tabular}{|l|c|c|c|c|c|c|c|}
\hline \multirow{3}{*}{ Atribut } & \multicolumn{5}{|c|}{ Hasil Kuisioner } & \multirow{2}{*}{$\begin{array}{c}\text { Total } \\
\text { Score }\end{array}$} & \multirow{2}{*}{ Tingkat Kepuasan } \\
\cline { 2 - 7 } & 1 & 2 & 3 & 4 & 5 & & \\
\hline Desain sederhana & & 2 & 5 & 10 & 3 & 74 & 3.7 \\
\hline Harga & 3 & 6 & 4 & 7 & & 55 & 2.75 \\
\hline Bahan & 5 & 4 & 9 & 2 & & 48 & 2.4 \\
\hline Mudah dalam penggunaan & 1 & 3 & 4 & 7 & 5 & 72 & 3.6 \\
\hline
\end{tabular}

Tabel 6. Hasil kepuasan konsumen

\begin{tabular}{|c|c|c|c|c|c|c|c|c|c|}
\hline $\begin{array}{l}\text { Customer } \\
\text { Need }\end{array}$ & IR & The & tio & ip & riks & $\begin{array}{l}\text { Total } \\
\text { Score }\end{array}$ & $\begin{array}{c}\text { Tingkat } \\
\text { Kepuasan }\end{array}$ & $\begin{array}{c}\text { Bobot } \\
(\%)\end{array}$ & Ranking \\
\hline $\begin{array}{l}\text { Desain } \\
\text { Sederhana }\end{array}$ & 4 & 3 & 1 & 1 & 0 & 74 & 3.7 & 29.72 & 1 \\
\hline Harga & 4 & 1 & 9 & 3 & 3 & 55 & 2.75 & 22.09 & 2 \\
\hline Bahan & 3 & 0 & 3 & 9 & 0 & 48 & 2.4 & 19.28 & 3 \\
\hline $\begin{array}{l}\text { Mudah } \\
\text { Dalam } \\
\text { Penggunaan }\end{array}$ & 4 & 1 & 0 & 0 & 9 & 72 & 3.6 & 28.91 & 4 \\
\hline
\end{tabular}


Hasil House of Quality (HOQ) Survei Akhir Produk Mainan Anak

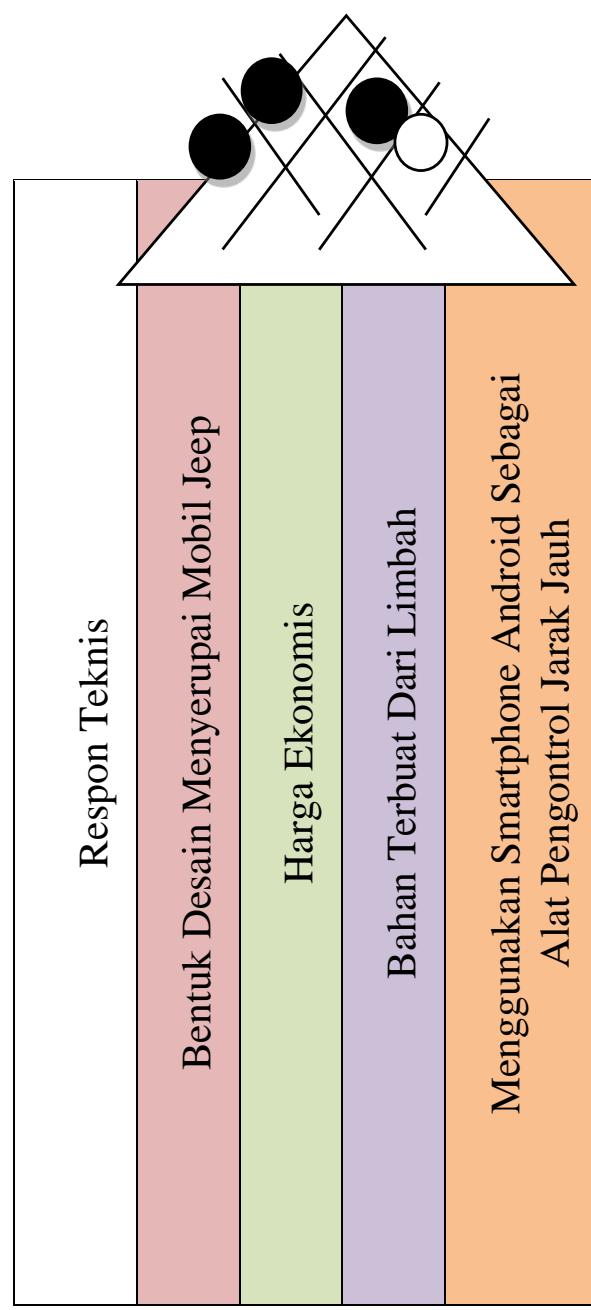

\begin{tabular}{|l|c|}
\hline \multicolumn{2}{|c|}{ Relationship Matriks } \\
\hline tidak ada & \\
\hline lemah & \\
\hline sedang & \\
\hline kuat & \\
\hline
\end{tabular}

\begin{tabular}{|l|c|}
\hline \multicolumn{2}{|c|}{ Customer } \\
\hline Strong+ & 0 \\
\hline Positive & $\bigcirc$ \\
\hline None & \\
\hline
\end{tabular}

Gambar 4. House of Quality (HOQ) hasil perancangan produk mainan anak

Berdasarkan dari hasil analisis matrik HOQ pada Error! Reference source not found. didapatkan bahwa hasil perhitungan bobot dan ranking terdapat dalam Error! Reference source not found.. Adapun produk jadi mainan anak yang diusulkan terdapat pada Gambar 5.

Tabel 7. Hasil kepuasan konsumen

\begin{tabular}{|l|l|l|c|c|c|}
\hline No & \multicolumn{1}{|c|}{ Atribut } & Respon Teknis & Ranking & $\begin{array}{c}\text { Tingkat } \\
\text { Kepuasan }\end{array}$ & Bobot (\%) \\
\hline 1 & $\begin{array}{l}\text { Desain } \\
\text { sederhana }\end{array}$ & $\begin{array}{l}\text { Bentuk desain } \\
\text { menyerupai } \\
\text { mobil jeep }\end{array}$ & 1 & 3.7 & 29.72 \\
\hline 2 & $\begin{array}{l}\text { Mudah } \\
\text { dalam } \\
\text { penggunaan }\end{array}$ & $\begin{array}{l}\text { Menggunakan } \\
\text { smartphone } \\
\text { android sebagai }\end{array}$ & 2 & 3.6 & 28.91 \\
\hline \multicolumn{5}{|r|}{ BRILIANT: Jurnal Riset dan Konseptual } \\
Volume 6 Nomor 2, Mei 2021
\end{tabular}




\begin{tabular}{|c|l|l|c|c|c|}
\hline & & $\begin{array}{l}\text { alat kontrol } \\
\text { jarak jauh }\end{array}$ & & \\
\hline 3 & Harga & Harga ekonomis & 3 & 2.75 & 22.09 \\
\hline 4 & & $\begin{array}{l}\text { Bahan terbuat } \\
\text { dari limbah } \\
\text { sehingga lebih } \\
\text { ramah } \\
\text { lingkungan }\end{array}$ & 4 & 2.4 & 19.28 \\
\hline
\end{tabular}

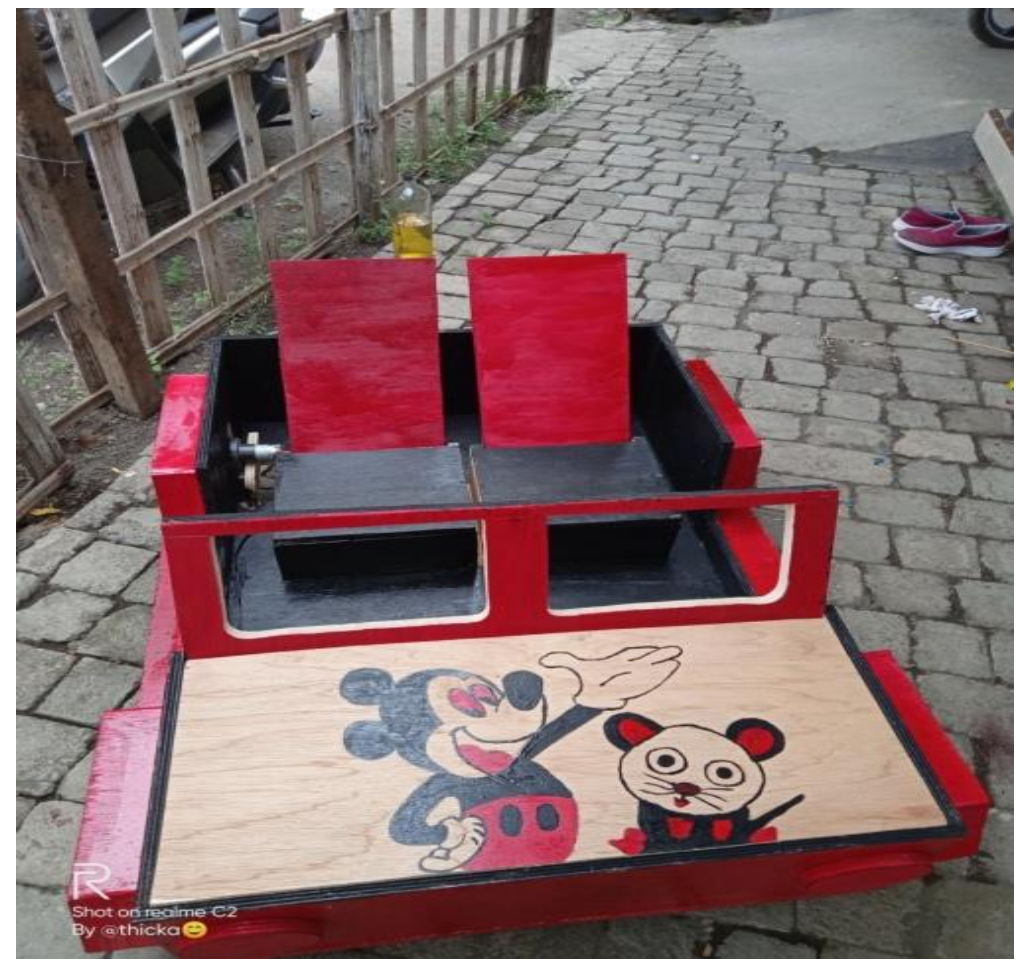

Gambar 5. Hasil produk hasil mainan anak

\section{KESIMPULAN}

Berdasarkan hasil analisis dan perancangan yang telah dilakukan, maka dapat diambil kesimpulan sebagai berikut: dengan adanya pengembangan produk mainan anak dari limbah triplek dapat mengurangi limbah triplek yang ada dilingkungan sekitar UD.345 dan meningkatkan nilai jual limbah.selain itu manfaat dari perancangan ini dapat meningkatkan harga jual produk mobil mainan anak dengan harga yang lebih ekonomis dan mengimbangi kualitas produk yang sudah ada di pasaran. Dan untuk mengetahui kepuasan konsumen maka dilakukan dengan menggunakan metode QFD dan menunjukkan bahwa konsumen lebih mengutamakan desain sederhana, mudah dalam penggunaan, harga dan bahan dari penelitian produk mainan anak.

\section{DAFTAR RUJUKAN}

Alia, T., (2018). Pendampingan Orang Tua pada Anak Usia Dini dalam Penggunaan Teknologi Digital. A Journal of Language, Literature, Culture, and Education POLYGLOT 14, 65-78.

452 BRILIANT: Jurnal Riset dan Konseptual Volume 6 Nomor 2, Mei 2021 
Astini, B.N., Nurhasanah, Nupus, H., (2019). Alat permainan edukatif berbasis lingkungan untuk pembelajaran saintifik tema lingkungan bagi guru paud korban gempa. Jurnal Pendidikan Anak 8, 1-6.

Dewi, Y.S., Purnomo, A., Nugroho, E.P., (2011). Kajian Penerapan House of Quality (HOQ) untuk Meningkatkan Kualitasi Layanan Kesehatan : Studi di GMC Health Center Yogyakarta. Jurnal Manajemen dan Pelayanan Farmasi $1,30-34$.

Nisa, L.C., (2012). Pemanfaatan Teknologi Informasi untuk Pengembangan Kemampuan Berhitung Anak Usia Dini. SAWWA 7, 91-112.

Suhendar, E., Suroto, (2014). Penerapan Metode Quality Function Deployment (QFD) dalam Upaya Peningkatan Kualitas Pelayanan Akademik pada UB. Faktor Exacta 7, 372-386.

Sutawidjaya, A.H., Asmarani, P.S., (2018). Evaluasi Pelayanan Publik Produk Hukum Online.com untuk Mengetahui Kebutuhan Pelanggan Kasus PT Justika Siar Publika. Jurnal JDM 1, 32-45.

Wagiono, Y.K., Hamrah, (2007). Metode Quality Function Deployment (QFD) untuk Informasi Penyempurnaan Perakitan Varietas Melon. Jurnal Agribisnis dan Ekonomi Pertanian 1, 48-57. 